\title{
Němčina v politice a diplomacii na Vysoké škole ekonomické
}

\author{
Eva Nováková
}

\begin{abstract}
Abstrakt: Článek seznamuje s výukou odborné němčiny zaměřené na oblast politiky a diplomacie na Vysoké škole ekonomické v Praze. Úvodem je představen systém jazykové výuky na Fakultě mezinárodních vztahů VŠE, bakalářský studijní program Mezinárodní studia - diplomacie a dva kurzy odborného jazyka určené pro tento program Němčina v mezinárodních studiích 1 a 2 . Podstatnou část př́íspěvku tvoří prezentace základního učebního materiálu Politik und Diplomatie auf Deutsch, který byl pro tyto kurzy vytvořen, a především různých metodických postupů při práci s ním. Uvedené jsou také doplňkové formy výuky - práce s politickými aktualitami, televizními zprávami a autentickými mediálními texty - včetně opakování gramatiky a forem testování. Závěrem se konstatuje, že v kurzech určených pro studenty bakalářského programu Mezinárodní studia - diplomacie lze také v němčině jako druhém cizím jazyce pracovat s odborným jazykem na pokročilé úrovni a vhodnými strategiemi motivovat studenty k jeho osvojování a upevňování.
\end{abstract}

Klíčová slova: němčina v politice a diplomacii - učební materiály - metodické postupy

Abstract: This paper deals with teaching of professional German focused on politics and diplomacy at the University of Economics in Prague. The introduction presents the system of language teaching at the Faculty of International Relations of the University of Economics, the bachelor study program International Studies - Diplomacy and two specialized language courses designed for this program German in International Studies 1 and 2. A substantial part of the paper is a presentation of the basic learning material Deutsch in Politik und Diplomatie that was created for these courses and especially various methodological procedures for working with it. Complementary forms of teaching - working with political news, television news and authentic media texts - are also included, including grammar review and testing. In conclusion, it is stated that in courses of German as a second foreign language intended for students of the bachelor program International Studies - Diplomacy, it can be worked with professional language at an advanced level and that by appropriate strategies, the students can be motivated to acquire and consolidate it.

Key words: German in politics and diplomacy, learning materials, methodical procedures

\section{Výuka cizích jazyků na Fakultě mezinárodních vztahů VŠE}

Vysoká škola ekonomická v Praze vždy kladla relativně velký důraz na jazykovou př́ípravu svých studentů. Nejvíce jazykové výuky poskytuje studentům tradičně Fakulta mezinárodních vztahů (FMV), která je jednou z největších z celkem šesti fakult VŠE a nabízí studium interdisciplinárních programů se silným mezinárodním přesahem. Značných úspěchů dosahuje fakulta $v$ oblasti internacionalizace studia, at' už jde o vysoký podíl studentů fakulty, kteří vyjíždějí na zahraniční studijní pobyty, počet studentů z cizích zemí a hostujících profesorů, mezinárod- 
ní akreditace studijních programů či studijní programy vyučované v angličtině. $\mathrm{V}$ průběhu studia mohou studenti FMV i jiných fakult VŠE získat mezinárodně uznávané jazykové certifikáty (z němčiny Goethe-Zertifikat B1, B2, C1) a zapisovat si povinné i volitelné kurzy různé úrovně pokročilosti a zaměření z celkem devíti nabízených jazyků včetně švédštiny a čínštiny, i když jsou tyto možnosti značně omezené nízkým počtem kreditů na volitelné předměty. Cizinci mohou navštěvovat kurzy češtiny $v$ anglickém jazyce. Až na výjimky disponují všechny jazykové předměty časovou dotací dvě hodiny, tj. jedna vyučovací jednotka o délce 90 minut, týdně a mají formu cvičení. Od absolventů Fakulty mezinárodních vztahů se očekává, že budou komunikovat minimálně ve dvou cizích jazycích na úrovni B2 až C1 Společného evropského referenčního rámce pro jazyky, a to včetně odborného ekonomického jazyka i odborného jazyka odpovídajícího jejich studijnímu programu. Jazykovou výuku na VŠE zajištují katedry anglického, německého a ruského jazyka a katedra románských jazykủ, které jsou součástí Fakulty mezinárodních vztahů.

V bakalářském studiu lze na FMV v prezenčním studiu v češtině studovat největší studijní program Mezinárodní obchod nebo dva menší programy Mezinárodní studia - Diplomacie

a Cestovní ruch. Jazykové výuce jsou pro všechny studijní programy vyhrazeny čtyři semestry odborného ekonomického jazyka se dvěma povinnými zkouškami, na které navazují dva semestry odborného jazyka zaměřeného na jednotlivé bakalářské programy a zakončené povinnou zkouškou. Všechny povinné jazykové kurzy a zkoušky musí studenti úspěšně absolvovat ve dvou cizích jazycích. $V$ magisterském studiu povinná jazyková výuka není. $V$ tomto článku chceme představit výuku odborného jazyka pro studijní program Mezinárodní studia - Diplomacie.

\section{Bakalářský studijní program Mezinárodní studia - Diplomacie a kurzy odborného jazyka šité mu na míru}

Cílem bakalářského studijního programu Mezinárodní studia - diplomacie je připravit odborníky pro oblast mezinárodních vztahů vybavené také standardními znalostmi z oblasti ekonomie, práva, statistiky a matematiky a nadstandardními jazykovými znalostmi. Obor je koncipován multidisciplinárně a ve výuce je kladen důraz na vzájemnou provázanost znalostí z ekonomické, politické, mezinárodně právní, bezpečnostní, kulturní a dalších oblastí. Absolventi oboru se mohou uplatnit jako pracovníci aparátu v zahraniční službě, asistenti mezinárodních útvarů v oblasti státní správy, jako pracovníci středního managementu v evropských i mezinárodních politických a ekonomických institucích a organizacích, dále jako manažeři mezinárodních projektů $\mathrm{v}$ nevládních organizacích, $\mathrm{v}$ agenturách sítě OSN i jako pracovníci v masmédiích. 
Studijní program Mezinárodní studia - diplomacie byl akreditovaný před 20 lety. Ve spolupráci s jeho hlavním garantujícím pracovištěm - Střediskem mezinárodních studií Jana Masaryka na FMV VŠE - jsme pro něj připravili dva kurzy specializovaného jazyka a akreditovali je pod názvem Němčina v mezinárodních studiích 1 a Němčina v mezinárodních studiích 2 . Cílem výuky v těchto kurzech je rozšíření slovní zásoby a rozvíjení ústních a písemných komunikačních dovedností v oblasti politiky a diplomacie. Po úspěšném absolvování kurzů mají být studenti schopni rozumět delším textům a mluvenému projevu ze studovaného oboru, vyjadřovat se plynně ústně i písemně k tématům z oblasti politiky a diplomacie, včetně formulování vlastního názoru, a zvládat jazykově i obsahově odborná témata probíraná v kurzu.

\section{Skripta Politik und Diplomatie auf Deutsch}

Základní učební materiál v kurzech Němčina v mezinárodních studiích 1 a 2 představují skripta Politik und Diplomatie auf Deutsch, které jsme vydali v roce 2014 jako aktualizovanou a přepracovanou verzi skript z roku 2007 Deutsch in Politik und Diplomatie. Obě publikace byly určeny kromě oboru Mezinárodní studia diplomacie také pro tehdejší bakalářský obor Politologie. Tematickou náplní korespondují skripta Politik und Diplomatie auf Deutsch se sylaby obou kurzů odborného jazyka v oblasti politiky a diplomacie. Skripta jsou rozdělena do 15 kapitol a v prvním kurzu se probírají kapitoly Úvod do politiky, Globální zahraniční a bezpečnostní politika, Lidská práva, Organizace spojených národů, Evropská unie, NATO a Úvod do diplomacie. Ve druhém kurzu se po úvodní kapitole Vládní systémy a nástroje kontroly moci v demokracii věnujeme politickým systémům České republiky, Německa, Rakouska a Švýcarska a moderním dějinám těchto německy mluvících zemí. Kurz i skripta končí kapitolou Základní formy diplomatické korespondence. Jednotlivé kapitoly obsahují kromě textů slovníček oborových výrazů, gramatická a lexikální cvičení, jejichž řešení studenti najdou v klíči na konci skript, a konverzační cvičení. Na konci skript mají studenti k dispozici také souhrnný slovník.

Hlavními prameny pro texty ve skriptech byly materiály německé vládní organizace Bundeszentrale für politische Bildung (Spolková centrála pro politické vzdělávání), která vydává širokou škálu publikací s politickými tématy určenými od starších žáků po vědce a zdarma zaslala všechny požadované materiály. Dále byly použity oficiální prameny vlád ČR a německy mluvících zemí. U politického systému ČR jsme vycházeli především z publikace Karla Vodičky Politisches System Tschechiens, 1996. V kapitolách věnovaných diplomacii a diplomatické korespondenci jsme čerpali z českých a německých publikací v tomto oboru a v oblasti diplomatické korespondence také ze spolupráce s JUDr. Aloisem Drhlíkem, který působil ve Středisku mezinárodních studií Jana Masaryka na FMV VŠE a poskytl řadu podkladů. 


\section{Metodické postupy při práci se skripty}

První kurz začínáme úvodem do politiky Was ist Politik? Čteme různé definice politiky od Aristotela, přes Machiavelliho, Napoleona až po lidové rčení Politik ist ein schmutziges Geschäft (politika je svinstvo). Některé definice překládáme, aby si studenti osvěžili práci s překladem odborného textu, který se často vyznačuje dlouhými souvětími a jeho překlad má v němčině svá úskalí kvůli častému umístění plnovýznamového slovesa na konci věty, množství interpunkcí neoznačených rozvitých př́vlastků a infinitivních vazeb. Studenti potom ve skupinách pomocí této slovní zásoby písemně formulují vlastní definice politiky a potom je v plénu prezentují. Vděčné konverzační téma $\mathrm{v}$ této kapitole představuje Politikverdrossenheit (znechucení politikou), které začínáme popisem a interpretací karikatury, následuje diskuse v plénu: Proč jsou lidé znechuceni politikou? Na ni naváže skupinová práce se cvičením, kdy studenti mají doplňovat do sloupců Real (jak vidím politiky) a Ideal (jaké bych je chtěl/chtěla mít). Studenti si přitom kromě řečových dovedností a odpovídajícího lexika procvičí i podmiňovací způsob. Politických karikatur je ve skriptech více a slouží nejen k odlehčení výuky, ale jejich popis a různé interpretace motivují k samostatnému ústnímu projevu a procvičení př́slušné slovní zásoby. Po úvodní kapitole pracujeme metodou zadávání četby textů a vypracování vybraných cvičení jako domácí př́ípravu na následující hodinu, ve které potom procvičujeme obsah textů a $\mathrm{v}$ nich použité slovní zásoby formou dotazů v plénu a práce ve dvojicích nebo ve skupinách. Studenti dostávají také prostor $\mathrm{k}$ formulování vlastních názorů na probíraná politická témata. Pro procvičení písemných dovedností mohou studenti fakultativně vypracovat eseje na zadané politické téma.

Hlavní tematickou náplň prvního kurzu tvoří mezinárodní organizace, při nichž se uplatňuje z velké části společná slovní zásoba. Studenti si ji mohou u tř́ organizací zopakovat a upevnit slovní spojení jako vstoupit do EU, NATO, OSN, vystoupit z organizace, účastnit se summitu / vojenské mise, přijímat závazná rozhodnutí, uvalit sankce, hájit zájmy, použít práva veta, zasahovat do vnitřních záležitostí jiného státu, dodržovat, porušovat smlouvy / lidská práva / zákony, členské státy spolupracují apod. Stejně tak si studenti u tématu Globální zahraniční a bezpečnostní politikaosvojí slovní zásobu jako studená válka, bipolarita, oslabování státu, nevládní organizace apod. 0 financování obrany zemí NATO a členství v něm lze diskutovat při popisu a interpretování karikatury Kostase Koufogiorgosse o NATO: „To je nový obchodní model NATO: méně penězi dosáhnout více."

Politické systémy České republiky a německy mluvících zemí, které tvoří spolu s moderními dějinami Německa, Rakouska a Švýcarska hlavní tematický obsah druhého kurzu, mají opět z velké části podobnou slovní zásobu. Opakují se spojení sestavit vládu, rozpustit parlament, právo předkládat návrhy zákonů, schvalovat zákony, jmenovat a odvolat ministra, vyjádřit neduvěru vládě, přijmout demisi, volební prá- 


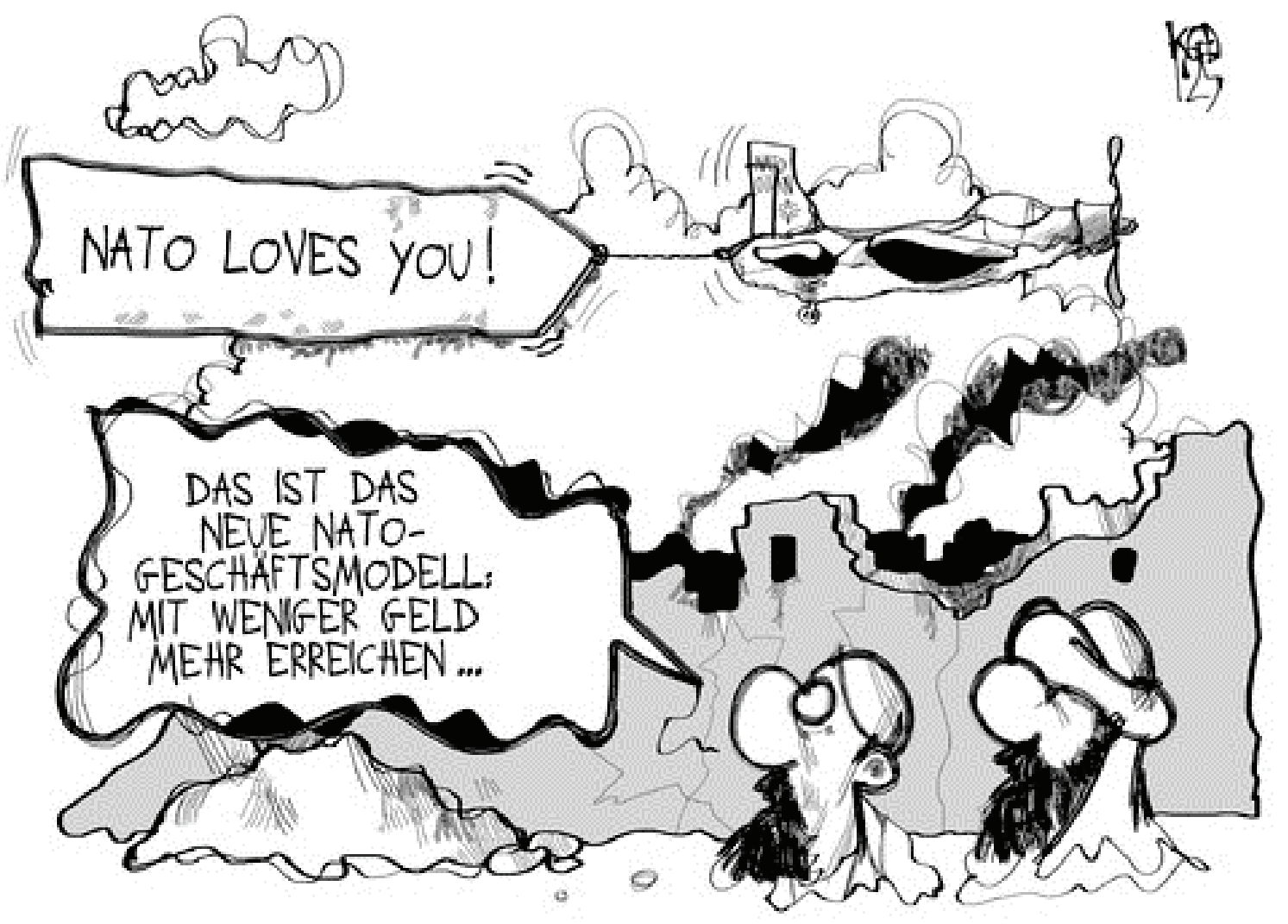

vo, volební období, hlasovat/volit podle většinového či poměrného volebního systému, právo udílet milost, prehlasovat veto, veřejná správa, regionální a místní samospráva apod. K upevnění odborné slovní zásoby i obsahu slouží ve skriptech také schémata politických systémů, do kterých studenti doplňují názvy politických subjektů z nabídky a vztahy mezi nimi: volí, jmenuje atd. Viz příklad politického uspořádání SRN.

V některých konverzačních cvičeních si studenti kromě slovní zásoby procvičí také gramatiku, např podmiňovací způsob v kapitole o České republice, v níž mohou ve skupinách diskutovat na téma: Jak byste změnili politický systém ve vaší zemi, kdybyste měli tu možnost? Při prezentací výsledků z jednotlivých skupin dochází k zajímavým diskusím. Ve skupinách je většinou několik studentů z jiných zemí, především ze Slovenska, a proto je možné pojmout politické systémy také komparativně.

$\mathrm{V}$ částech věnovaných dějinám německy mluvících zemí od 2 . světové války se studenti naučí v němčině slovní spojení jako jsou stát byl rozdělen do okupačních zón, založen, byly provedeny reformy či pojmy jako kolektivizace, zestátnění, hospodářská zázrak, politika uvolňováni, sjednocení, trvalá neutralita, lidové hlasování, kolegiální systém a prrímá demokracie, která představuje stále aktuální téma $\mathrm{k}$ diskuzím. 
Tragen Sie folgende Begriffe in die entsprechenden Lücken des Schaubildes ein. Bundesverfassungsgericht, Landesparlamente/Landtage, Bundestag, wahlberechtigte Bevölkerung, Landesregierungen, Bundeskanzler, Bundesminister, Bundesrat, Bundespräsident, Bundesversammlung

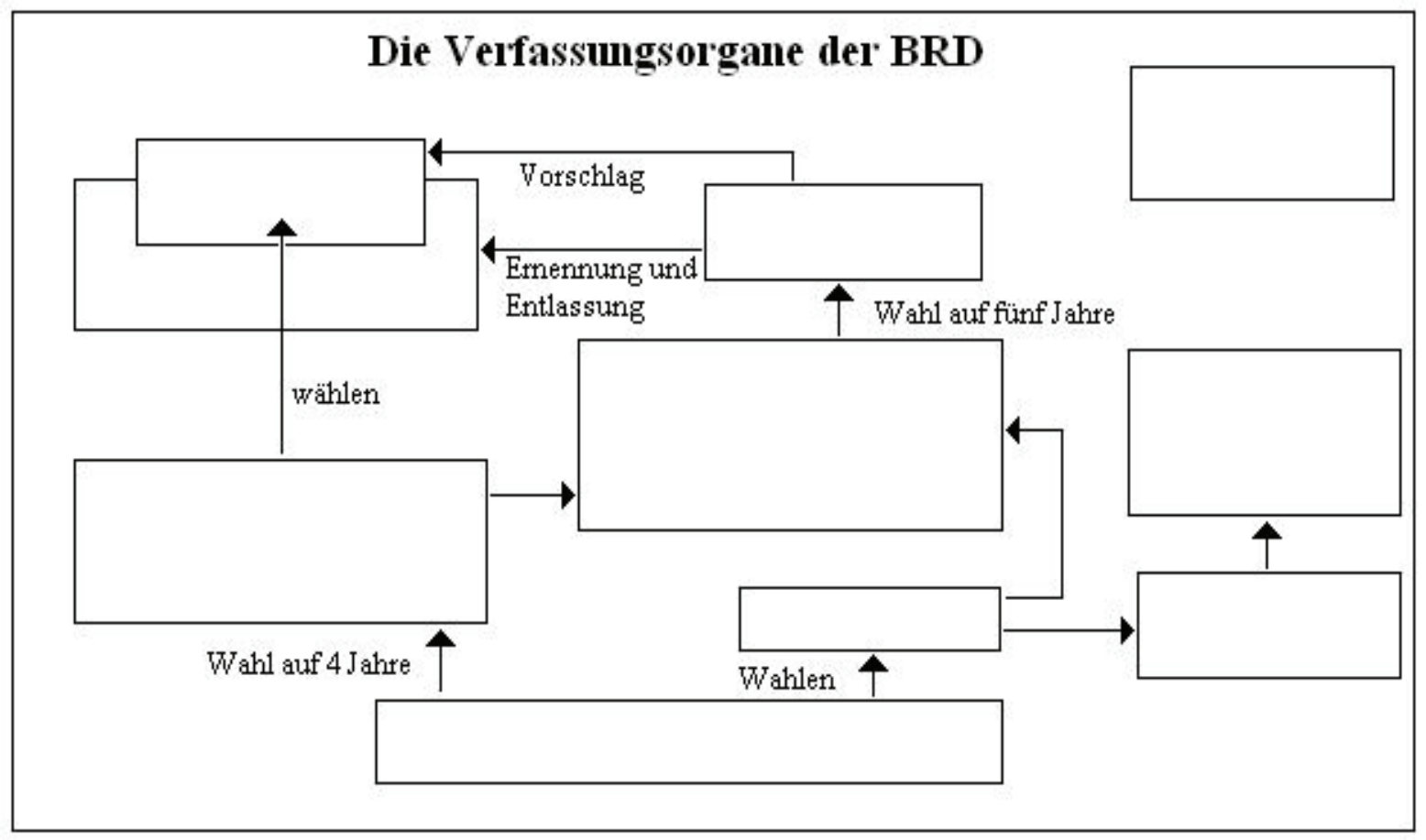

V kapitole věnované diplomacii jsou stručně uvedeny dějiny diplomacie, charakter současné diplomacie, multilaterální a ekonomická diplomacie, navazování a přerušení diplomatických vztahů a diplomatický protokol, státní orgány pro zahraniční vztahy, diplomatické mise a konzuláty, diplomatická imunita. Při jejich probírání se studenti naučí odpovídající slovní zásobu. Totéž platí pro kapitolu o diplomatické korespondenci. Po úvodní krátké charakteristice diplomatické korespondence a jejího rozdělení podle odesílatele a př́jemce diplomatických listin jsou popsány nejběžnější typy těchto listin jako pověřovací a odvolávací listiny, osobní/personální nóta, verbální nóta atd. Diplomatický písemný styk mezi Českou republikou a německy mluvícími zeměmi probíhá $\mathrm{z}$ historických důvodů $\mathrm{v}$ němčině, ač celosvětově přebrala po francouzštině i $v$ této oblasti hlavní úlohu angličtina. Proto uvádíme ve skriptech kopie několika autentických diplomatických listin, které jsme získali $\mathrm{z}$ archivu Ministerstva zahraničních věcí a zveřejnili je $\mathrm{s}$ jeho laskavým svolením. Při četbě a překladu pověřovacích listin, které patří k nejstarším a nejvíce formou svázaným typům diplomatické korespondence, diskutujeme o stylu jazyka listiny - komplikovaný, archaický, slavnostní, vznešený - a značné formalizaci diplomatických styků. Studenti mají být schopni zformulovat důvody dodržování detailně předepsaných forem styků v diplomacii. Jsou jimi především 
K podpoře samostatného mluveného projevu dobře slouží např́klad fotografie berlínské zdi. Studenti mohou vyjádřit, co o berlínské zdi vědí, proč byla postavena a proč se stala symbolem studené války, která strana patří do západní a která do východní části Berlína a proč si to myslí. $V$ té souvislosti lze mluvit o hranicích mezi tehdejší Východní a Západní Evropou, proč byly př́ísně střežené a o porušování lidských práv v komunistických zemích.

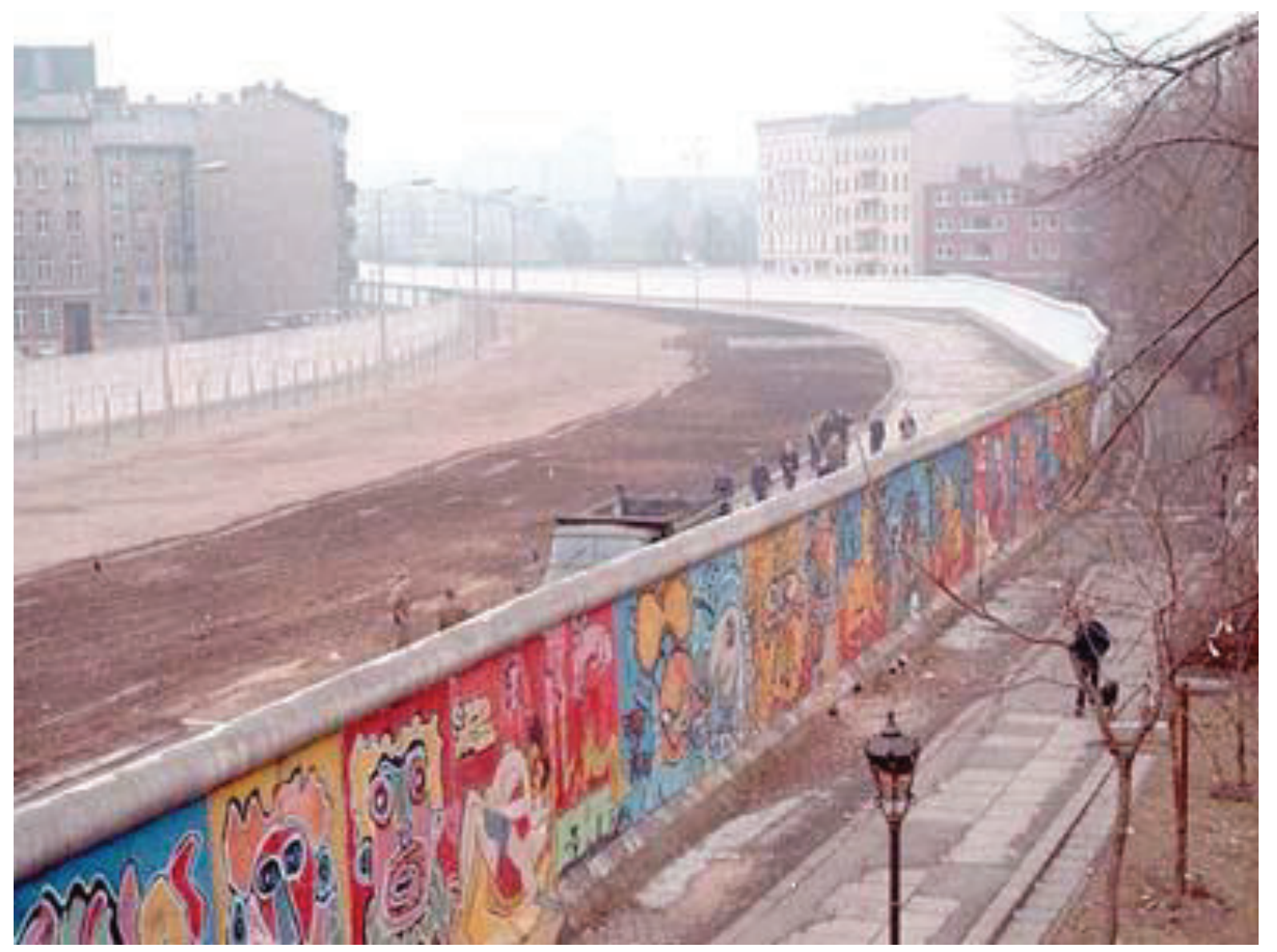

snaha vrhnout se dezinterpretacím a nedorozuměním, a tím konfliktům mezi státy.

Příkladem lpění na formě v diplomatickém ústním i písemném styku jsou také pevně stanovená oslovení vedoucích diplomatických, politických, akademických a církevních reprezentantů, jejichž stručný výtah je uveden ve skriptech. Nejvyšší představitelé zemí jako hlavy států, předsedové vlád, velvyslanci či nejvyšší představitelé mezinárodních organizací a církve jsou oslovováni (Eure) Exzellenz (Vaše) Excelence, král a královna (Eure) Majestät (Vaše) Veličenstvo, princ a princezna z vládnoucího rodu (Eure) Königliche Hoheit (Vaše) Královská Výsosti, princ a princezna z nevládnoucího rodu (Eure) Durchlaucht (Vaše) Jasnosti/Milosti. V této souvislosti lze porovnat roli formy při diplomatických stycích monarchií a republik, 
O problémech německého sjednocování lze diskutovat s pomocí karikatury Ulricha Forchnera z roku 1991.
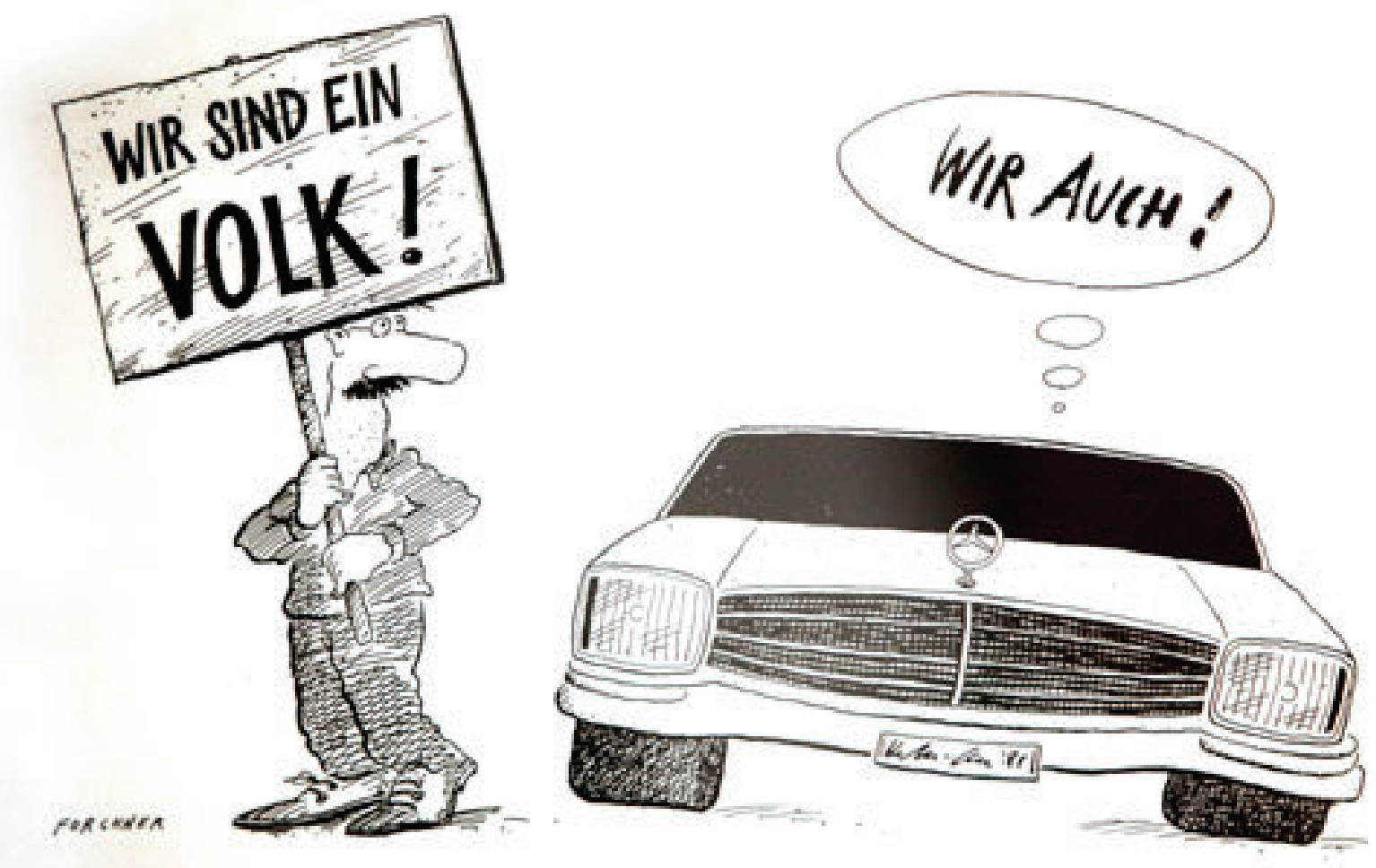

přičemž monarchie i v demokratických a rovnostářských zemích, jako jsou skandinávské, kladou v této oblasti větší důraz na formu a tradici než země s republikánským zř́zením.

Po absolvování obou kurzů včetně dvou kapitol z diplomacie mají být studenti schopni vyjádřit německy věty jako například Vláda vysílající země dává podnět ke jmenování nového velvyslance. Vedoucí diplomatické mise nastupuje od úřadu slavnostním předáním pověrovacích listin hlavě státu přijímací země.

\section{Doplňkové formy výuky - politické aktuality, televizní zprávy a autentické mediální texty}

Na každou hodinu si studenti automaticky připravují krátkou politickou aktualitu, kterou většinou prezentují sousedovi a potom v plénu bud' reprodukují aktualitu souseda, nebo diskutují o nosných politických tématech jako např́íklad brexit, střet zájmů, aktuální volby apod. Tato forma se velmi osvědčila, studenti mají skoro 
vždy aktualitu připravenou a prezentace aktualit ve dvojicích rozšiřuje možnosti rozvíjení řečových dovedností. Výukové skupiny jsou většinou dvacetičlenné a studenti se hodin němčiny pilně účastní, proto je vhodné přerušovat frontální výuku a diskuse v plénu krátkou konverzací ve dvojicích či tř́, maximálně čtyřčlenných skupinách, aby studenti dostali více prostoru pro mluvený projev.

Oblíbené je u studentů sledování televizních zpráv. Většinou používáme zpravodajství veřejnoprávního programu Zweites Deutsches Fernsehen, které umožňuje sledovat zprávy s německými titulky. Při výběru reportáže je třeba dbát na to, aby byla jazykově srozumitelná, ne př́liš dlouhá a zároveň splňovala požadavek zajímavosti a motivování k diskusi. Stejná kritéria musí splňovat i autentické texty z deníků či týdeníků německé jazykové oblasti (Die Zeit, Die Welt, FAZ, Der Spiegel, Die Presse, Der Standard, Neue Zürcher Zeitung event. Radio Prag apod.), jichž několik během semestru přečteme a pak o nich diskutujeme.

\section{Gramatika v pokročilých kurzech odborné němčiny}

Němčina je pro většinu studentů druhým cizím jazykem, kterému je na základní a střední škole věnovaný podstatně menší počet výukových hodin než prvnímu jazyku angličtině. Tomu odpovídají průměrné vstupní znalosti. Proto se také v kurzech odborného jazyka snažíme zopakovat některé gramatické jevy, zvláště ty, které se často vyskytují v odborném jazyce, jako trpný rod, infinitivní konstrukce nebo rozvitý př́vlastek. Užitečné je i opakování minulého času a podmiňovacího způsobu. Studenti dostávají mailem přehledy gramatických jevů, které si mohou procvičit na převážně substitučních, transformačních a také překladových cvičeních ve skriptech. Většina gramatických cvičení slouží nejen k zopakování gramatických jevů běžných $\mathrm{v}$ odborném jazyce, ale i $\mathrm{k}$ upevnění nové slovní zásoby. Vycházíme tak vstříc studentům, z nichž většina opakování a procvičování gramatiky vyžaduje. Vedle gramaticko-lexikálních cvičení jsou v každé lekci cvičení na porozumění čtenému textu a komunikativní cvičení určená pro práci ve dvojicích či ve skupině.

\section{Testování a závěrečná zkouška}

V prvním semestru musí studenti úspěšně absolvovat dva písemné testy, ve druhém semestru mají předepsanou prezentaci na libovolné politické téma ve dvou až třičlenných skupinách a zkoušku, která má písemnou a ústní část. Písemné testy nejsou na rozdíl od testů $v$ kurzech hospodářského jazyka elektronické, protože jejich hlavní část tvoří esej, v níž se ověřuje jazyková a obsahová znalost probraných témat (např. politický systém Německa, vývoj Rakouska po 2. světové válce apod.). Zároveň mají studenti $\mathrm{v}$ testu formulovat svůj názor na dílčí téma (např. role Německa v Evropské unii, migrační krize apod.). Deset tematických okruhů pro ústní zkoušku zahrnuje hlavní probíraná témata z obou semestrů, např́íklad politické 
systémy států včetně jejich zahraniční politiky a aktuální politické situace. Studenti tak musí umět německy vyjádřit zaměření vládnoucích stran jako křest'anští, sociální a občanští demokraté, liberálové, zelení apod.

\section{Závěr}

I když v posledních letech klesá u studentů VŠE průměrná úroveň vstupních znalostí němčiny a ochota se na výuku a testy připravovat, patří studenti programu Mezinárodní studia - diplomacie stále k těm nejmotivovanějším a hodnotí kladně kurzy odborného jazyka „šité na míru“ jejich studijnímu zaměření. Velká část z nich klade vysoké požadavky na učitele i na sebe, o čemž svědčí také jejich pozitivní přístup k doplňkovým aktivitám při výuce. Výsledkem je, že v jazykových kurzech určených studentům tohoto žádaného studijního programu lze v němčině jako druhém cizím jazyce pracovat s odborným jazykem na pokročilé úrovni (B2 až C1) a vhodnými strategiemi motivovat studenty k jeho osvojování a upevňování. Brzdu většího prohloubení řečových dovedností však představuje nízká hodinová dotace pro jazykovou výuku.

\section{Literatura}

GEYER, R. (2013). Politik für Einsteiger. Bonn: Bundeszentrale für politische Bildung.

MAIER, G. (1998). Was ist Politik? Bonn: Bundeszentrale für politische Bildung.

NovÁková, E. (2007). Deutsch in Politik und Diplomatie. Praha: Oeconomica.

NovÁKová, E. (2014). Politik und Diplomatie auf Deutsch. Praha: Oeconomica.

Pötzsch, H. (2005). Die deutsche Demokratie. Bonn: Bundeszentrale für politische Bildung.

ŠRonĚK, I. (2005). Diplomatický protokol a praktické otázky společenské etikety. Praha: Karolinum.

VodičKA, K. (1996). Politisches System Tschechiens. Münster: LIT Verlag.

\section{Autorka}

PhDr. Eva Nováková, Katedra německého jazyka Fakulta mezinárodních vztahů VŠE Praha, e-mail: eva.novakova@vse.cz, Katedra německého jazyka FMV VŠE, nám. W. Churchilla 4, 13067 Praha 3

Autorka vystudovala němčinu a švédštinu na FF UK a od roku 1987 působí na Katedře německého jazyka VŠE. Garantuje kurzy Němčina v mezinárodních studiích 1 a 2 , kurzy švédštiny a kurzy němčiny pro začátečníky a mírně pokročilé v anglickém programu, v nichž také učí. Řadu let učila v kurzech hospodářské němčiny. Zaměřuje se na jazyk politiky, diplomacie a médií v němčině. 